\title{
Carcinoembryonic Antigen Peptide
}

National Cancer Institute

\section{Source}

National Cancer Institute. Carcinoembryonic Antigen Peptide. NCI Thesaurus. Code C49272.

A class of synthetic peptides based on the sequences of carcinoembryonic antigen (CEA), a tumor-associated antigen overexpressed in several cancer cell types. These peptides may be used in vaccination ag ainst cancers. 